\title{
Eco-Friendly Processing of Sulfidic Polymetallic Concentrates Using Biohydrometallurgy
}

\author{
Maxim Muravyov ${ }^{1}$, Natalya Fomchenko ${ }^{1}$ \\ ${ }^{1}$ Winogradsky Institute of Microbiology, Research Center of Biotechnology of the Russian Academy of Sciences \\ Leninsky Ave., 33, bld. 2, Moscow, Russia \\ maxmuravyov@inmi.ru; natalya.fomchenko@inmi.ru
}

\begin{abstract}
Pyrometallurgical processing of sulfidic ores for recovery of non-ferrous metals is a traditional method. It requires the use of high-grade concentrates with high metal content, which are usually produced by flotation. A delay in exploration and exploitation of new deposits resulted in the involvement of lower-grade ores and ores with complex compound composition in the treatment. The development of methods for the processing of polymetallic difficult-to-beneficiation sulfidic concentrates is a relevant issue. In this paper, an eco-friendly technology for polymetallic sulfidic ore processing is proposed. It includes a biohydrometallurgical step for processing of low-grade polymetallic sulfidic concentrate and a pyrometallurgical step for processing of high-grade concentrates. The biotechnological step of the technology is a combination of leaching of the concentrate with biogenic ferric iron and bioregeneration of leaching solution with the use of acidophilic microorganisms. The results are relevant to the development of a two-step biohydrometallurgical technology for processing of copper-zinc concentrate with a closed cycle of technological flows. This technology could be a promising technique to reduce the environmental hazard of metallurgical plants.
\end{abstract}

Keywords: biohydrometallurgy, bioleaching, sulfidic concentrates, mining wastes, acidophilic microorganisms

\section{Introduction}

Traditional pyrometallurgical processes for metal recovery from its ores and concentrates consist of chemical reactions at elevated temperatures. These processes generally use sulfides and, in some cases, high-grade oxides. The use of high temperatures for metallurgical processing offers several advantages, chemical reaction rates are rapid and some reactions that are impossible to occur at low temperatures can take place at elevated temperatures. Depending on the minerals and the type of equipment, pyrometallurgical recovery may take place in as many as four steps: flotation, roasting, smelting, and refining. Mining and metallurgical treatments of sulfide ores are presently characterized by significant losses of non-ferrous and precious metals into the various wastes. Flotation of sulfidic ores yields formation sulfide flotation tailings, whereas roasting produces sulfur dioxide and smelter slags. These wastes pose a problem not just because of their sheer volume and aerial extent, but some of them may affect local ecosystems. The heavy metals existing in the sulfide minerals can be released to the liquid phase during weathering. Sulfide oxidation results in sulfuric acid [1].

Reserves of high-grade sulfide ores from the exploited deposits are gradually depleted and their quality is affected. A delay in exploration and exploitation of new deposits in Russia resulted in the involvement of lower-grade ores and ores with complex compound composition in the treatment. Nowadays, $70-75 \%$ of the raw material base of mining and processing plants of the Urals are already represented by refractory ores for which an application of flotation technologies does not allow to obtain high-grade concentrates [2].

The development of methods for the processing of polymetallic sulfidic concentrates is a relevant issue. Biotechnologies for the treatment of sulfide mineral raw materials based on the application of acidophilic chemolithotrophic microorganisms for the leaching of nonferrous metals and recovery of noble metals are economically more attractive and have relatively little impact on the environment than traditional pyro- and hydrometallurgical technologies [3]. Based on the study and determination of optimal parameters for oxidation reactions of sulfide minerals, the processes of obtaining metals directly at the deposits of these metals were developed, thus becoming the first biogeotechnologies introduced on an industrial scale. At present, up to $20 \%$ of copper in the world is received using the biohydrometallurgical method $[4,5]$. There is a large number of enterprises using heap 
leaching under natural conditions for copper production [6-8]. An attractive way to use acidophilic microorganisms from sulfide deposits is by implementing the stirred tank biohydrometallurgical technologies for the production of gold and nonferrous metals, which have a higher intensity compared to heap leaching and in situ leaching [9-11].

One of the approaches to intensification of the biohydrometallurgical treatment of sulfidic raw materials is to separate the process between chemical and biological steps and to create optimal conditions for each of them [2, 12-14]. During the chemical step, sulfidic minerals are oxidized by ferric iron ions, which are further reduced to ferrous iron ions. Further, ferrous iron ions oxidation to ferric iron ions, i.e. oxidizer bioregeneration, is conducted by microorganisms during the separate biological step.

The goal of the present work was to propose an eco-friendly technology based on biohydrometallurgical techniques for polymetallic sulfidic ores processing.

\section{Experimental}

A polymetallic sulfidic concentrate used in this study was obtained from ore of the Tarnierskoe deposit (Sverdlovsk region, Russia). Contents of the main sulfidic minerals were $(\%)$ : chalcopyrite $\left(\mathrm{CuFeS}_{2}\right) 42.1$, sphalerite $(\mathrm{ZnS}) 7.5$, pyrrhotite $\left(\mathrm{Fe}_{1-\mathrm{X}} \mathrm{S}\right)$ 24.0, and pyrite $\left(\mathrm{FeS}_{2}\right)$ 12.5. Contents of the main elements were (\%): zinc 5.00, copper 14.7, iron 33.9, sulfur 34.3, calcium $<0.1$, silicon 1.16 .

Leaching of the concentrate with biogenic ferric iron was conducted in a reactor that contained $1.0 \mathrm{~L}$ of pulp. The stirring rate was $760 \mathrm{rpm}$, and the temperature was maintained by heat exchangers connected to a thermostat. The leaching was conducted under batch conditions. The solid phase was loaded and mixed with the biologically generated $\mathrm{Fe}^{3+}-$ containing solution. The $\mathrm{Fe}^{3+}$-containing solution was obtained by biooxidation of ferrous sulfate in $9 \mathrm{~K}$ medium [15] at 30 ${ }^{\circ} \mathrm{C}$ with a microbial culture containing Acidithiobacillus ferrooxidans and Leptospirillum spp. The liquid was preheated to the desired temperature. The $\mathrm{pH}$ of the pulp was continuously monitored, and sulfuric acid (98.5\%) was added when necessary to maintain $\mathrm{pH}$ value at 1.3 . The leaching was carried out cyclically; after each cycle, the suspension was centrifuged, and the residue was supplemented with a new portion of the ferric-containing solution for the next cycle of leaching.

\section{Results and Discussion}

\subsection{An eco-friendly technology for processing of sulfidic polymetallic ores}

An eco-friendly technology for polymetallic sulfidic ore processing using a biohydrometallurgy is shown in Fig. 1. Sulfidic ores are concentrated via traditional flotation techniques, obtaining high-grade monometallic concentrates and difficult-to-beneficiate low-grade polymetallic concentrates. A biohydrometallurgical processing, including leaching with biogenic ferric iron at elevated temperature and bioregeneration of leaching solution with the use of acidophiles, is proposed to treat such low-grade polymetallic concentrates. During the leaching step, mainly zinc and partially copper are extracted into the aqueous phase in the form of sulfates. Zinc is able to be recovered from the aqueous phase by traditional methods (for example, solvent extraction). Copper from the pregnant leach solution after the step of leaching can be recovered by traditional solvent extraction and electrowinning (SX-EW).

$\mathrm{SO}_{2}$ gas produced during the pyrometallurgical processing of high-grade concentrates can be used as a raw material for the production of sulfuric acid. Approximately $20 \%$ of world sulfuric acid production is obtained from high $\mathrm{SO}_{2}$ strength metallurgical off-gases. However, the complexity and capital cost of acid production may not be justified and sitespecific factors may not favor direct production of sulfuric acid; for instance, in remote sites with small acid consumption and demand. It is estimated that operational costs and ecological risk may exceed potential profit gained from sulfuric acid production in remote regions, such as Siberia in Russia. 


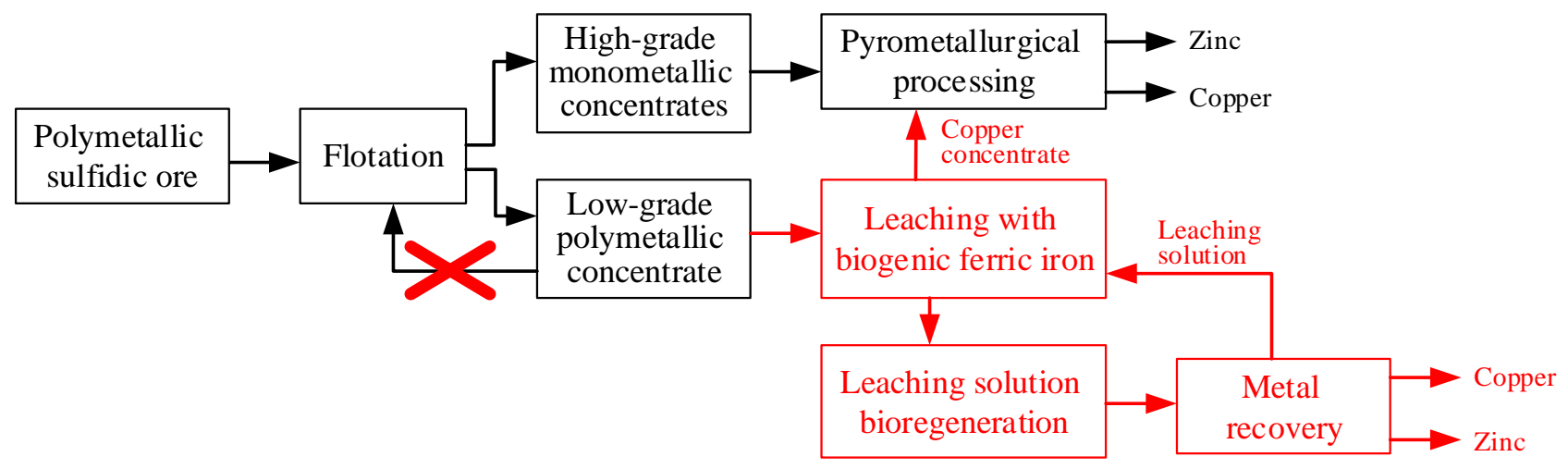

Fig. 1: A new technology for polymetallic sulfidic ore processing with application of biohydrometallurgy.

\subsection{A copper-zinc concentrate processing at biotechnological step of the technology}

The composition of the concentrate used for this study includes sulfidic minerals (chalcopyrite, sphalerite, and pyrrhotite), whose oxidation with ferric sulfate can be represented as the following simplified equations:

$$
\begin{gathered}
\mathrm{CuFeS}_{2}+2 \mathrm{Fe}_{2}\left(\mathrm{SO}_{4}\right)_{3}=\mathrm{CuSO}_{4}+5 \mathrm{FeSO}_{4}+2 \mathrm{~S}^{0} \\
\mathrm{ZnS}+\mathrm{Fe}_{2}\left(\mathrm{SO}_{4}\right)_{3}=\mathrm{ZnSO} 4+2 \mathrm{FeSO}_{4}+\mathrm{S}^{0} \\
\mathrm{FeS}+2 \mathrm{Fe}_{2}\left(\mathrm{SO}_{4}\right)_{3}=3 \mathrm{FeSO}_{4}+\mathrm{S}^{0}
\end{gathered}
$$

Sulfidic minerals are known to have different oxidation kinetics in sulfate solutions of ferric iron. Chalcopyrite possesses higher energy of crystal lattice and forms passivation layers on the surface during leaching. This determines its high refractoriness in iron sulfate solutions during biooxidation. Also, chalcopyrite is known to be oxidized most intensively at relatively low redox potential of the medium (to $450 \mathrm{mV}$ ), while sphalerite and pyrrhotite destruction is intensified with the increase in oxidizer concentration and, hence, in the redox potential of the medium $[16,17]$. Galvanic interactions between sulfidic minerals are also observed. Thus, pyrrhotite and sphalerite are oxidized first, whereas chalcopyrite and pyrite are the last to be oxidized [18, 19]. At the same time, one can suppose that zinc and part of iron can be removed selectively from the chalcopyrite-sphalerite product and most of copper can be left in the solid phase.

Leaching of the concentrate with biogenic ferric iron was studied. Effects of oxidizer concentration, $\mathrm{pH}$, pulp density, temperature, and duration of leaching were found. The best results on metals recovery and their contents in leach residue were obtained at $80{ }^{\circ} \mathrm{C}, \mathrm{pH} \mathrm{1.3,} \mathrm{ferric} \mathrm{iron} \mathrm{initial} \mathrm{concentration} \mathrm{in} \mathrm{the} \mathrm{leaching} \mathrm{solution} \mathrm{at} 19 \mathrm{~g} / \mathrm{L}$, pulp density 10\%, and three cycles of leaching (1st - $40 \mathrm{~min}, 2 \mathrm{nd}-90 \mathrm{~min}$, and 3rd - $210 \mathrm{~min}$ ) (Table 1).

Table 1: Metal contents in leach residue and their recoveries into the aqueous phase.

\begin{tabular}{|l|l|l|l|}
\hline \multicolumn{2}{|l|}{ Content in solid phase $(\%)$} & \multicolumn{2}{|l|}{ Extraction into aqueous phase (\%) } \\
\hline $\mathrm{Cu}$ & $\mathrm{Zn}$ & $\mathrm{Cu}$ & $\mathrm{Zn}$ \\
\hline 15.6 & 0.14 & 25.0 & 98.0 \\
\hline
\end{tabular}

The leach residue is considered to be a high-grade copper concentrate with a low content of zinc. This copper concentrate can be processed via traditional pyrometallurgical methods. The leach solution after metal recovery can be regenerated for the ferric leaching by its biooxidation with the use of acidophilic microorganisms [3, 20].

\section{Conclusion}

An eco-friendly technology for polymetallic sulfidic ore processing was proposed. It is based on a combination of pyro- and biohydrometallurgical steps: high-grade sulfidic concentrates are processed via pyrometallurgy, and lowgrade polymetallic sulfidic concentrates are processed via biohydrometallurgy. This technology could be a promising technique to reduce the environmental hazard of metallurgical enterprises. Efficient conditions of a high-temperature 
ferric leaching process were determined as follows: $80{ }^{\circ} \mathrm{C}, \mathrm{pH} 1.3$, ferric iron initial concentration in the leaching solution at $19 \mathrm{~g} / \mathrm{L}$, pulp density $10 \%$. Leaching of the polymetallic concentrate with biogenic ferric iron allows producing a highgrade copper concentrate which can be processed via pyrometallurgy.

\section{Acknowledgements}

The financial support provided by the Russian Science Foundation is gratefully acknowledged [project 18-74-00003].

\section{References}

[1] B. G. Lottermoser, Mine Wastes. Berlin, Heidelberg: Springer-Verlag, 2007.

[2] N. V. Fomchenko and M. I. Muravyov, "Two-step biohydrometallurgical technology for modernization of processing of sulfidic copper-zinc products," Hydrometallurgy, vol. 174, pp. 116-122, 2017.

[3] N. V. Fomchenko and M. I. Muravyov, "Two-step biohydrometallurgical technology of copper-zinc concentrate processing as an opportunity to reduce negative impacts on the environment," J. Environ. Manag., vol. 226, pp. 270$277,2018$.

[4] D. B. Johnson, "Development and application of biotechnologies in the metal mining industry," Environ. Sci. Pollut. Res., vol. 20, pp. 7768-7776, 2013.

[5] C. L. Brierley, "How will biomining be applied in future?" Trans. Nonferr. Met. Soc. China., vol. 18, pp. 1302-1310, 2008.

[6] H. R. Watling, "The bioleaching of sulphide minerals with emphasis on copper sulphides - A review," Hydrometallurgy. vol. 84, pp. 81-108, 2006.

[7] H. R. Watling, "Review of biohydrometallurgical metals extraction from polymetallic mineral resources," Miner., vol. 5, pp. 1-60, 2015.

[8] S. Panda, A. Akcil, N. Pradhan, H. Deveci, "Current scenario of chalcopyrite bioleaching: A review on the recent advances to its heap-leach technology," Biores. technol., vol. 196, pp. 694-706, 2015.

[9] C. L. Brierley and J. A. Brierley, "Progress in bioleaching: part B: applications of microbial processes by the minerals industries," Appl. Microbiol. Biotechnol., vol. 97, pp. 7543-7552, 2013.

[10] A. H. Kaksonen, N. J. Boxall, Y. Gumulya, H. N. Khaleque, C. Morris, T. Bohu, K. Y. Cheng, K. Usher, A. M. Lakaniemi, "Recent progress in biohydrometallurgy and microbial characterization," Hydrometallurgy, vol. 180, pp. $7-25,2018$.

[11] A. Mahmoud, P. Cezac, A. F. A. Hoadley, F. Contamine, P. D'Hugues, "A review of sulfide minerals microbially assisted leaching in stirred tank reactors," Int. Biodeterior. Biodegrad., vol. 119, pp. 118-146, 2017.

[12] N. V. Fomchenko, T. F. Kondrat'eva, M. I. Muravyov, "A new concept of the biohydrometallurgical technology for gold recovery from refractory sulfide concentrates," Hydrometallurgy, vol. 164, pp. 78-82, 2016.

[13] M. I. Muravyov and N. V. Fomchenko, "Leaching of nonferrous metals from copper converter slag with application of acidophilic microorganisms," Appl. Biochem. Microbiol., vol. 49, no. 6, pp. 562-569, 2013.

[14] N. Smalley and G. Davis, "Operation of the Las Cruces ferric sulphate leach pilot plant," Miner. Eng., vol. 13, no. 6, pp. 599-608, 2000.

[15] M. P. Silverman and D. G. Lundgren, "Studies on the chemoautotrophic iron bacteria Ferrobacillus ferrooxidans. An improved medium and harvesting procedure for securing high yields," J. Bacteriol., vol. 77, pp. 642-647, 1959.

[16] F. Crundwell, A. Van Aswegen, L. Bryson, C. Biley, D. Craig, V. Marsicano, J. Keartland, "The effect of visible light on the dissolution of natural chalcopyrite $\left(\mathrm{CuFeS}_{2}\right)$ in sulphuric acid solutions," Hydrometallurgy, vol. 158, pp. 119-131, 2015.

[17] J. Song, L. Gao, J. Lin, H. Wu, J. Lin, "Kinetics and modeling of chemical leaching of sphalerite concentrate using ferric iron in a redox-controlled reactor," Chin. J. Chem. Eng., vol. 21, no. 8, pp. 933-936, 2013.

[18] B. C. Patel, M. K. Sinha, D. R. Tipre, A. Pillai, S. R. Dave, "A novel biphasic leaching approach for the recovery of $\mathrm{Cu}$ and $\mathrm{Zn}$ from polymetallic bulk concentrate," Biores. Technol., vol. 157, pp. 310-315, 2014.

[19] F. Estrada-de los Santos, R. E. Rivera-Santillán, M. Talavera-Ortega, F. Bautista, "Catalytic and galvanic effects of pyrite on ferric leaching of sphalerite," Hydrometallurgy, vol. 163, pp. 167-175, 2016.

[20] N. V. Fomchenko, M. I. Muravyov, V. S. Melamud, "Bioregeneration of leaching solutions during two-step processing of copper-zinc concentrate," Appl. Biochem. Microbiol., vol. 54, no. 4, pp. 432-435, 2018. 